がに同所衛生化学課長蔵行義雄博士に深謝いたします。 (昭和 37 年 11 月, 第 16 回日 本薬学大会に㧍いて一部発表

\section{交献}

1）厚生省：“食品添加物公定書”, p. 77, 275(1960).

2）北川純男，豊田勤治：衛生試， 74，243(1956).

3) E. Cerma : Rass. Chim. per chim. e ind., 12, No.1, 13 (1960) ; Chem. Abstr., 55, 1953 (1961).

4) 志方益三，館 勇：農化，8，954（1932).

$$
\text { is }
$$

Polarographic study of water-soluble azo dyes. (Polarographic study of artificial food colors. I.) Yasuhisa Mizunoya and Takako Kita (The Osaka City Institute of Hygiene, Kita-ku, Osaka)

The polarographic behaviors of eight watersoluble azo compounds used as artificial food colors-Food Orange No. 1 (Orange I), Food Red No. 101 (Ponceau R), Food Red No. 1 (Ponceau 3R), Food Yellow No. 5 (Sunset Yellow FCF), Food Red No. 4 (Ponceau SX), Food Red No. 2 (Amaranth), Food Red No. 102 (New Coccine) and Food Yellow No. 4 (Tartrazine)-were studied in buffered solutions at $\mathrm{pH} 1.0 \sim 14.0$, with $0.1 M$ tetramethylammonium chloride as a supporting electrolyte. All these dyes gave well defined waves in acidic medium, which corresponded with two electrons reduction except for Food Red No. 102.

When the $\mathrm{pH}$ of solution became higher in the acidic range, the half-wave potentials shifted remarkably to negative, but the shifts were not so great in the alkaline side. Moreover, the second waves appeared at lower $\mathrm{pH}$ in the order of numbers ( 3,2 and 1$)$ of acid radicals in the dye molecules, and became irreversible as the $\mathrm{pH}$ became higher.

It could be concluded that the limiting currents of the azo compounds were diffusion currents, because the observed temperature coefficients in acidic solutions on the limiting currents from $15^{\circ} \mathrm{C}$ to $35^{\circ} \mathrm{C}$ ranged $1.3 \sim 2.2 \%$ per degree and the limiting currents were proportional to square roots of the hights of mercury reservoir.

The eight water-soluble azo compounds of the concentrations $10^{-3} \sim 10^{-4} \mathrm{M}$ could easily be determined polarographically in acidic solutions.

(Received Nov. 24, 1964)

\title{
ベンゾヒドロキサム酸とのかっ色錯化合物を抽出する 微量バナジウムの吸光定量法の改良*
}

\author{
宮本 正俊**，片桐 正武***
}

\begin{abstract}
従来, 種々難点があったベンゾビロキサム酸による微量バナジウムの抽出吸光定量法を検討して, でく簡単な操作により精度よく定量する方法を提出した．本法では $\mathrm{pH}$ 緩衝剤が妨害イオンの被覆剤と しても働き，バナジム（V) は試薬の有機溶媒溶液により発色と同時に抽出される．抽出試薬溶液は 調製が容易であり，少なくとも2 简月間は有効である． $\mathrm{pH}$ の許容範囲は著しく広い。次の操作により バナジウム 2.8〜約 $90 \mu \mathrm{g}$ を定量できる.

試料溶液にマロン酸 $0.0444 \sim 0.0556 M$ を加え, $\mathrm{pH}$ を $2.8 \sim 4.4$, 容積を $25 \mathrm{ml}$ にする. てれを試 薬 $0.144 \sim 0.171 \%$ を含む 3 -ヘプタノール $5 \mathrm{ml}$ で 3 分間振り, 抽出層の $450 \mathrm{~m} \mu$ に打りる吸光度を 水を対照にして $1 \mathrm{~cm}$ 吸収そうで測る.抽出層の色は少なくとも 2 日間は安定である. 鉄 (III)，モリ ブデン (VI)，白金 (IV) 打よびタングステン (VI) はそれぞれ 1.0，0.50，1.25 打よび $0.001 \mathrm{mg}$ 以下であるてとを要するが，チタン (IV) その他の普通のイオンは少なくとも $2.0 \mathrm{mg}$ まであっても さしつかえない. ピロリン酸ナトリウムを $0.02 M$ 加えると, 鉄の共存許容量は少なくも $5 \mathrm{mg}$ までふ える。
\end{abstract}

\footnotetext{
* 微量バナジウムの吸光定量 (第 1 報)

** 東海電極製造株式会社 : 藤沢市大鋸天神台 **** 東海電極製造株式会社：藤沢市大鋸天神台
}

現在 東北薬科大学分析化学教室 : 仙台市原町小田原南光沢

現在 日本ポリウレタン工業株式会社 : 横浜市保土ケ谷区天王町 


\section{1 まえがき}

数多く報告されたバナジウムの吸光定量法のなかで, ベンゾヒドロキサム酸 $\left\{\mathrm{C}_{6} \mathrm{H}_{5} \mathrm{C}(: \mathrm{NOH}) \mathrm{OH}\right\}$ をバナシ ウム $(\mathrm{V})$ の発色試薬にする方法は感度がきわめて高 く, また試薬が安価である.この試薬ははじめ, Singh そ Das Gupta1)によってバナジウム (V)，モリブデン (VI), ウラン (VI) などの点滴法による検出に 用いら れたが，のちに，かれらによってバナジウムの吸光定 量2)に発展された。そののち，この試薬によって水層に 生じるかっ色のバナジウム錯化合物を，有機溶媒で抽出 する吸光定量法により, 鋼と石油 ${ }^{3}$, 六フッ化ウランと酸 化ウラン4), 動物(体5), 植物(体6)などの試料中のバナジウ ムが定量された。しかし，これら抽出吸光定量法は妨害 イオンの除去, 試薬の 調製法, 抽出溶媒の安定性, $\mathrm{pH}$ の許容範囲などに難点がある．また，かっ色錯化合物が 水層で著しく不安定なので, ただちに有機溶媒で抽出し なければ色あせる心配がある．著者らは，これらの難点 を避けることを試みて，マロン酸を $\mathrm{pH}$ 緩衝郕および妨 害イオンの被覆剂として試料溶液に加えたのち，3-ヘプ タノールに溶かした試薬溶液で，バナジウムを発色と同 時に抽出する吸光定量法を得た. 本法の操作はきわめて 簡単であり，感度も著しく高い。

\section{2 定 量 法}

本法は 3 に述べる実験結果と考察を基にして得られた ものであり, バナジウム $2.8 〜$ 約 $90 \mu \mathrm{g}$ を定量できる. なお， $450 \mathrm{~m} \mu$ より長波長で吸光度を測れば，さらに多 量のバナジウムも定量できる.

\section{$2 \cdot 1$ 装置と菜品}

财光度の測定には分光光度計と $1 \mathrm{~cm}$ 财収そうを用い る.著者らは日立 EPU-2A 型を用いた。薬品は特に断 らないかぎり JIS 特級品または保証品を用いる。なお， 本法の検討にも同じものを用いたが，吸収曲線の測定に は日立 EPS-2 型自記分光光度計と $1 \mathrm{~cm}$ 吸収そうを用 いた。

抽出試薬溶液：ベンゾヒドロキサム酸 $0.160 \mathrm{~g}$ を 3ヘプタノール $100 \mathrm{~m} l$ に溶かす。とれは少なくとも2 箇 月以上たくわえうる，著者らは，東京化成特級品を酢酸 エチルで 2 回再結晶したベンゾヒドロキサム酸と, 東京 化成 1 級品を無水炭酸ナトリウムで脱水後蒸留して得た 3ーヘプタノールを用いた。

マロン酸緩衝溶液 : $0.500 M$ マロン酸 5 部に $0.500 M$ 水酸化ナトリウム 1 部を混ぜる. このものはマロン酸根 について $0.278 M$ であり, $\mathrm{pH} 3.4$ である.
バナジウム標準溶液：メタバナジン酸アンモニウムを 溶かしてつくる. 著者らは，アンモニア水に溶かしたの ち, 塩化アンモニウムを加えて析出てさせた精製品を用 いて, バナジウム $2.92 \mathrm{mg} / \mathrm{ml}$, 塩酸 $0.60 \mathrm{~N}$ の溶液を つくった．てれは, バナジウム濃度を重量分析で定めた のち，適当にうすめて用いた。

\section{$2 \cdot 2$ 定贯操作}

試料溶液を発色用メスフラスコ8)にとり，䘏酸または アルカリでフェノールフタレイン中性にしたのち, マロ ン酸緩衝溶液 $4.0 \sim 5.0 \mathrm{~m} l$ と水を加えて $25 \mathrm{~m} l$ にする. これによって溶液の $\mathrm{pH}$ は約 3.4 になる. 抽出試薬溶 液を正確に $5 \mathrm{ml}$ 加兑て約 3 分間振ったのち, 約 3000 $\mathrm{rpm}$ で約 5 分間遠心分離する。抽出層をスポイトて $1 \mathrm{~cm}$ 吸収そうに移し，その吸光度を水を対照にして $450 \mathrm{~m} \mu$ ，波長幅 $1 \mathrm{~m} \mu$ で測る.

試料溶液の $\mathrm{pH}$ を調節する別法として，マロン酸紱衝 溶液の代わりに $0.5 M$ マロン酸を $2.5 \mathrm{ml}$ 加光たのち, 2,4 -ジニトロフェノールの黄色点まて酸またはアルカリ を加元てもよい，検量線は約 $90 \mu \mathrm{g}$ 以下の種々の量の バナジウムを用いて上記の操作に従ってつくる.

\section{3 実験結果と考察}

以下の検討における実験は，特に断らないかぎり 2 に 準じて行なった.

\section{$3 \cdot 1$ 水溶液で生じるバナジゥム錯化合物}

バナジウム $(\mathrm{V})$ 溶液にベンゾヒドロキサム酸（以下 単に試薬とよぶ) の水溶液を加え, $\mathrm{pH}$ を種々に調節し た際についた色を $40 〜 100$ 分後の吸収曲線で Fig. 1 に 示す. 曲線 I は $\mathrm{pH} 2.3$ で得られたかっ色の吸収曲線で あり, $460 \mathrm{~m} \mu$ の吸収帯が他の色の吸収帯よりも強い. $\mathrm{pH}$ を 6.6，8.5 および 10.0 亿したとき注，可逆的に， それぞれ淡黄色（曲線 III），㤸か色（曲線 IV）およ び無色（曲線 V) になった。曲線 II は $\mathrm{pH} 3.9$ で得ら れたものであり，曲線Iから曲線III 亿移る途中である. 従来, 弱酸性では赤色, アンモニアアルカリ性では紫色 の錯化合物を生じるといわれている22が，pH の変化に よる吸収曲線の変化が上記のように複雑であるので, 試 薬とバナジウムの反応生成物についてはさらに検討が必 要である.

これら $\mathrm{pH}$ 領域で得られる色はどれも不安定であり， 放置によって著しく色あせる、たとえば，バナジウム $35.1 \mu \mathrm{g} / \mathrm{m} l$ にモル比で 18 倍の試薬を加兄, $\mathrm{pH} 2.2$ で発色させた 溶液の吸光度は, 約 10 分後に $0.95,30$ 分後に 0.79 であった. 退色の速さは散光下でも暗处で 


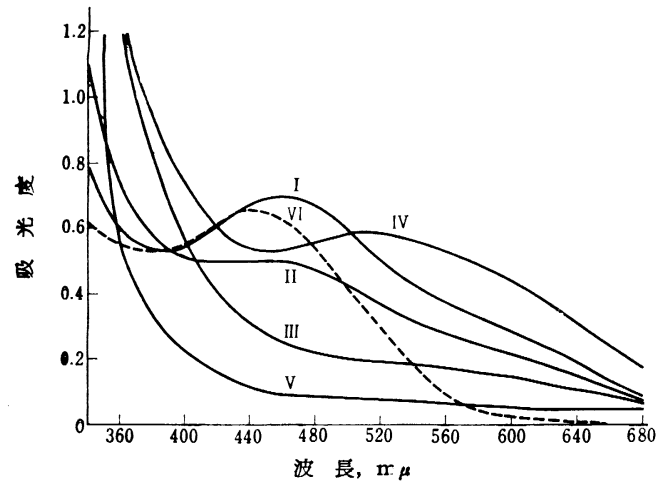

Fig. 1 バナジウム錯体の吸収曲線

\begin{tabular}{|c|c|c|c|c|c|}
\hline 曲線 & 溶媒 & $\mathrm{V}(\mu \mathrm{g} / \mathrm{m} l)$ & & 偏 & \\
\hline I & 水 & 35.12 & pH 2.3, & 試蒕 $1.21 \times 10^{-2} M$, & 緩衙剤なし \\
\hline II & " & " & " 3.9 , & " & " \\
\hline III & " & " & " 6.6, & " & " \\
\hline IV & " & " & " 8.5, & " & " \\
\hline $\mathbf{v}$ & " & " & " 10.0, & " & " \\
\hline VI & 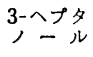 & 8.78 & $\begin{array}{l}0.0200 M \\
0.160 \% \text { 政 }\end{array}$ & 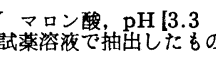 & の溶液から \\
\hline
\end{tabular}

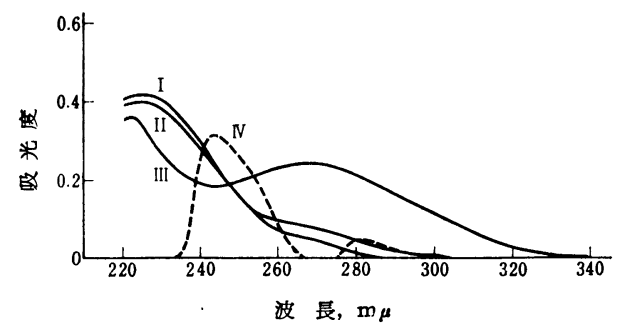

Fig. 2 試薬の吸収曲線

\begin{tabular}{|c|c|c|c|}
\hline 曲 線 & 溶 媒 & 試薬鋠度 & 酸・アルカリ性度 \\
\hline I & 水 & $4.83 \times 10^{-5} M$ & pH $1.7 \sim 7.0$ \\
\hline II & " & " & pH 8.0 \\
\hline III & " & " & $0.59 \mathrm{~N} \mathrm{NaOH}$ \\
\hline IV & 3-ヘプタノール & $7.01 \times 10^{-5} M$ & - \\
\hline
\end{tabular}

も変わりない。 また，pH が低い場合ほど速く色あせ る.

試薬の溶液は Fig. 2 に示すように紫外部の光を吸収 する.アルカリ性にすると，新しく $270 \mathrm{~m} \mu$ の吸収帯を 生じるが，これは変化が可逆的であるから，試薬のイオ ン解離によるものであろう.

\section{$3 \cdot 2$ 有機溶液によるかっ色錯化合物の抽出}

アルカリ性側の $\mathrm{pH}$ 領域で生じる呈色物質は有機溶媒 で抽出されない. 従来, 酸性側で生じるかっ色錯化合物 は溶媒抽出されることが知られている．水層のかっ色錯 化合物は著しく退色するので，吸光定量に利用するに は，これを有機溶媒で抽出して安定にしなければならな い. 従来はバナジウムを水層中で発色したのち溶媒で抽 出したが，本法では，バナジウム溶液を試薬の有機溶媒 溶液で振って発色と同時に抽出する方針をとった。

$3 \cdot 2 \cdot 1$ 抽出溶媒の選択 従来, 試薬 とバナジウム （V）によって生じる種々の呈色化合物は, 脂肪族アル コール，エーエル，エステルなどの構造酸素を含む有機 溶媒で抽出されるが，炭化水素などの構造酸素を含ま ないものでは抽出されないといわれ(3)9，1-ヘキサノー

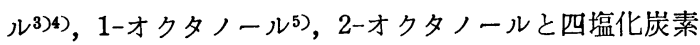
の混合物(6), ジイソブチルケトン9) などが，かっ色錯化 合物の抽出に用いられた。しかし著者らは，これら溶媒 の選択理由に満足できないので, 従来すでに検討された ものも含めて, 新たに数種の溶媒を検討した. Table I に, pH 3.3 の水溶液中で発色させて得たかっ色錯化合 物をただちに各種有機溶媒で抽出したときの結果を示 す. 抽出層の吸収曲線はどの有機溶媒の場合でもほとん ぞ同形であり， $450 \mathrm{~m} \mu^{3}$ ) に吸収極大がある（Fig. 1-曲 線VI)．これら有機溶媒のうち 3-ヘプタノールの場合は 抽出層の吸光度が大きく, また抽出による有機溶媒層の

Table I 各種有機溶媒によるかっ色錯化合物の抽出

\begin{tabular}{|c|c|c|c|c|c|c|c|}
\hline 有 機 溶 媒 & 比 重 ${ }^{(0)}$ & ${ }_{\left({ }^{\circ} \mathrm{C}\right)}{ }^{\text {点 }}{ }^{10)}$ & 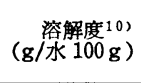 & $\begin{array}{l}\text { 抽出層 } \\
\text { の 色 }\end{array}$ & $\begin{array}{l}2 \text { 層分離 } \\
\text { 状 㑷 }\end{array}$ & $\begin{array}{l}\text { 抽出雾の } \\
\text { 容䅖 } \\
(\%)\end{array}$ & 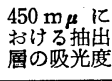 \\
\hline 1-ブタノール & 0.810 & 117.7 & 7.9 & かっ色 & 良 & 著しく負 & - \\
\hline 1-ペンタノール & 0.814 & 138 & 2.7 & " & $" \prime$ & 著しく負 & - \\
\hline $1-へ \neq サ ノ ー ル$ & 0.819 & 157.2 & 0.59 & " & " & -0.5 & 0.560 \\
\hline 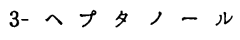 & 0.823 & 156.2 & 0.45 & " & 11 & -0.2 & 0.819 \\
\hline 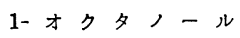 & 0.825 & 195 & 微 量 & $" \prime$ & $" 1$ & 0.8 & 0.805 \\
\hline メチルイソブチルケトン & 0.803 & 116.9 & 不 溶 & $" \prime$ & " & - & 0.326 \\
\hline シクロヘキサノン & 0.948 & 156.7 & 2.4 & " & " & -39.0 & 1.220 \\
\hline 酢 酸 プチル & 0.882 & 126.5 & 0.5 & 黄 色 & 不 良 & & 0.138 \\
\hline
\end{tabular}

発色条件 : V $58.5 \mu \mathrm{g}$; 武薬 $1.21 \times 10^{-3} M$; $\mathrm{pH} 3.3$; 全容積 $25 \mathrm{ml}$

抽出条件: 有機溶媒 $5.00 \mathrm{ml}$; 振り混ぜ時間 3 分間

†文献 8) の方法で測った值 
容積変化が最も小さい. しかも, この溶媒の沸点は蒸留 精製や取扱いに手ごろである.これらの点から，3-ヘプ タノールを抽出試薬溶液の溶媒に用いることにした.な 抢この溶媒で抽出した抽出層の吸光度は, 過剩に試薬を 加えて十分発色させた直後の水層の吸光度と比べると, 抽出による濃縮効果から期待される吸光度の約 2.5 倍で あって, 溶媒効果による吸収の強化が著しい. シクロへ キサノール，アセトフェノン，エーテルなどは構造酸素 を含むが，かっ色錯化合物を抽出しえない．

$3: 2 \cdot 2$ 抽出試楽溶液, 抽出率および色の安定性 試 薬を溶かした有機溶媒で振って, バナジウムを発色々同 時に抽出する方法は，かっ色錯化物が分解する危険がな いほか, 操作も簡単である. 本法の抽出試薬溶液は, き わめて簡単につくることができ, 普通の条件で 2 箇月間 保存しても, 効力が全く变わらないほど安定である. 従 来法3 〜5)では試薬は水溶液にして用いられたが, 水に溶 けにくく,アルカリ性では著しく不安定なので, 試薬溶 液の調製に手間がかかった. また, 抽出溶媒の保存によ る分解生成物 ${ }^{11}$ が，かっ色錯化合物を分解して定量を妨 げた ${ }^{3) 4}$. 本法ではこれらの難点が全くない。な打抽 試薬溶液は Fig. 2-曲線 IV からわかるように, かっ色 銧化合物の可視部における吸光度測定を妨げない。

抽出試薬溶液で, バナジウムを反覆抽出した際の抽出 層の吸光度を Table II に示す. この結果から, 1 回の 抽出でバナジウムがほとえど全部抽出されることがわか

Table II バナジウムの反覆抽出

\begin{tabular}{|c|c|}
\hline 抽出順序 & 抽出層の $450 \mathrm{~m} \mu$ における吸光度 \\
\hline 第 1 回 & 0.650 \\
\hline 第 2 回 & 0.009 \\
\hline 第 3 回 & 0.001 \\
\hline
\end{tabular}

$\mathrm{V} 43.9 \mu \mathrm{g} ;$ マ マロン酸 $0.020 M ; \mathrm{pH} 3.3 ; 0.160 \%$ 抽出試薬溶液

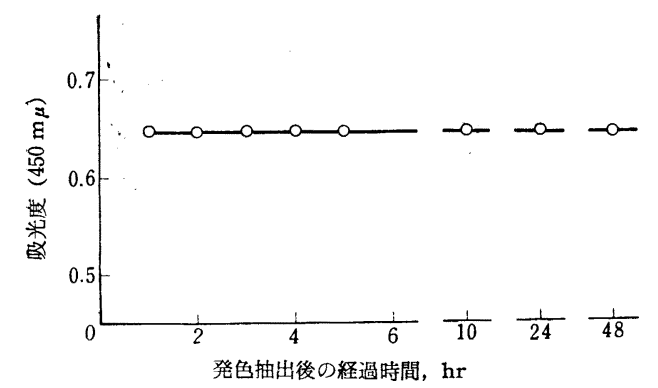

Fig. 3 抽出層の吸光度の経時変化

$\mathrm{V}: 43.9 \mu \mathrm{g}$ ； マロン酸: $0.0200 M ; \mathrm{pH}: 3.3$ ； 抽出試薬溶液の鋠度 : $0.144 \%$
る. 抽出層の色は安定であり, Fig. 3 に示すように少な くとも 2 日間は吸光度が变わらない。

\section{$3 \cdot 3 \mathrm{pH}$ 緩街剤の影響}

従来, $\mathrm{pH}$ 緩衝戍としてグリシンら) や酢酸アンモニウ ム6) が用いられたが，各種金属イオンが定量を妨げるの でこれらイオンを繁雑な方法で除く必要があった。も し, $\mathrm{pH}$ 緩衝戍が妨害イオンの被覆剤としても働くなら ば, 定量操作は大いに簡単になる.しかし，バナジウム も同時におおわれて, 試薬との反応がおさえられる心配 がある．著者らは金属錯塩を生成しやすい数種の有機酸 を $\mathrm{pH}$ 緩衝剂に用い，これら酸がバナジウムの発色を妨 げる状態を調べた。すなわち，有機酸を加えたバナジウ 么溶液に試薬を加えて発色させ，生じたかっ色錯化合物 をただちに 1ーヘキサノールで抽出して抽出層の吸光度 を測った. Table III に結果を示す.この結果は試薬濃 度, $\mathrm{pH}$, 抽出溶媒の種類などによって変わるであろう が，有機酸の種類による違いの傾向を知ることができ る.この結果に基いて，マロン酸を $\mathrm{pH}$ 緩衝戍および妨 害イオンの被覆剤として用いることにした.

水層のマロン酸濃度が増すにつれて, 抽出試薬溶液に よるバナジウムの抽出がおさえられる.この状態をFig. 4 に示す. この結果から，少なくも $\mathrm{pH} 3.4$ において は，マロン酸が $0.0556 M$ 以下ならば， $0.144 \%$ 以上の

Table III 抽出に及ぼす $\mathrm{pH}$ 緩衝剂の影㗽

\begin{tabular}{|c|c|c|c|}
\hline & \multicolumn{2}{|c|}{$\mathrm{pH}$ 緩衝㨈 } & 抽出層の $450 \mathrm{~m} \mu$ における吸光度 \\
\hline & な & ᄂ & 0.560 \\
\hline & シ こウ & 酸 & 0.000 \\
\hline & マ ロ ン & 酸 & 0.523 \\
\hline & ク $エ$ & 酸 & 0.270 \\
\hline 酒 & 酉 石 & 酸 & 0.450 \\
\hline
\end{tabular}

発色条件：V $58.5 \mu \mathrm{g} ; \mathrm{pH}$ 緩衙剂 $0.025 M ; \mathrm{pH} 2.7$; 試薬濃度 $1.21 \times 10^{-3} M$; 全容皘 $25 \mathrm{ml}$

抽出条件: 抽出溶媒 1 -ヘキサノール $5.00 \mathrm{ml}$; 振り混せ時間 3 分間

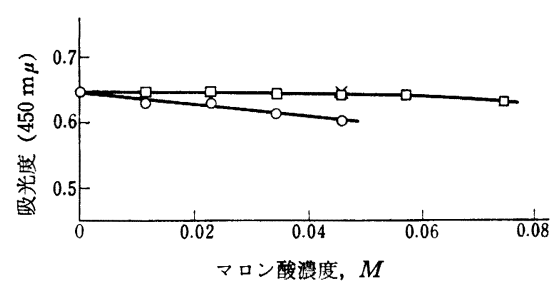

Fig. 4 マロン酸濃度の影響

$\mathrm{V}: 43.9 \mu \mathrm{g} ; \mathrm{pH}: 3.4$

- $\mathrm{O}-0.128 \%$ 抽出試灌溶液

$-\square-0.144 \% \quad " \quad$
$-\times-0.171 \% \quad$ 
試薬を含む抽出試薬溶液で振って, 一定の吸光度を示可 抽出層が得られることがわかる.

\section{$3 \cdot 4$ 酸性度と抽出試来㴽度の影響}

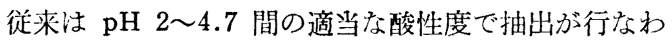
れた3つ 仿か，適当な $\mathrm{pH}$ 範囲に対与る試薬濃度の影響は 検討されていない. 本法に抢ける抽出試薬溶液によるバ ナジウムの抽出はバナジウムに対する抽出試薬とマロン 酸の競合反灾である.したがって, マロン酸の濃度が増 せ汸，バナジウム注抽出されにくくなって抽出に適当な $\mathrm{pH}$ 範囲が狭くなり, 逆に抽出試薬溶液の濃度が増せ ば, $\mathrm{pH}$ 範囲が広くなるはずである. 著者らはマロン酸 が比較的うすい場合の抽出に及ぼす $\mathrm{pH}$ の影響を調べて, Fig. 5-曲線 I で示す結果を得た。こ机によると， pH

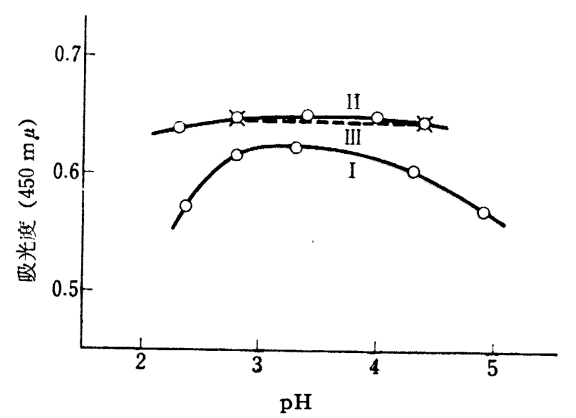

Fig. 5 酸性度の影響

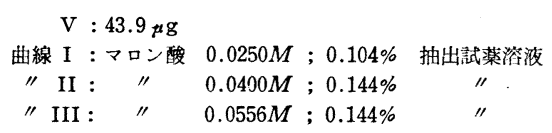

3.5 付近でバナジウムが最もよく抽出される.抽出試薬 溶液の濃度を少し增せば, 曲線 II と III で示すように, マロン酸の湍度が相当增したにもかかわらず，抽出に適 当な $\mathrm{pH}$ 範囲が広く得られる。すなわち, 抽出試薬溶液 の濃度が $0.144 \%$ 以上ならば，マロン酸が $0.0556 M$ あ

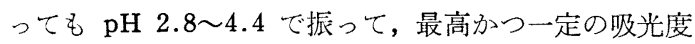
を示声抽出層が得られる。この $\mathrm{pH}$ 範囲は抽出試薬溶液 の滥度を増せばさらに広がるであるらが，後述のよう に, $\mathrm{pH}$ の調節がきわめて容易なので，乙れ以上の広範 囲を必要としないであろう。なお，水層の $\mathrm{pH}$ 注抽出前 後で差がない。

抽出層の吸収曲線の形は，実験した $\mathrm{pH}$ 範囲ではみな 同じであった。 また，この吸収曲線の形は，抽出試薬溶 液の濃度が違っても変わらない。すなわち Fig. 6 亿示 す結果は, 抽出試薬溶液の濃度が増すにつれて, 抽出層 の各波長における吸光度が平行して増している。なお，

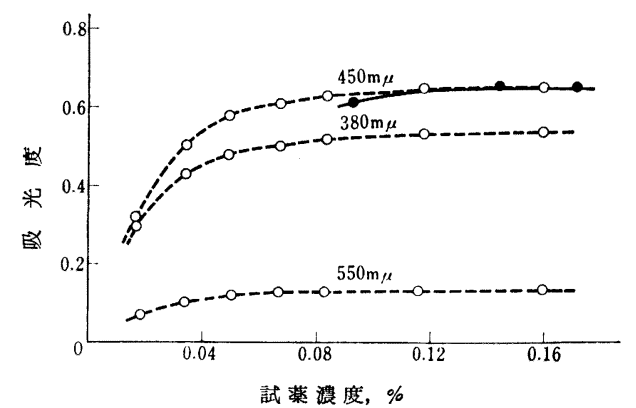

Fig. 6 抽出試薬溶液濃度の影響

$$
\begin{array}{cc}
\mathrm{V}: 43.9 \mu \mathrm{g} ; & \mathrm{pH}: 3.3 \\
\text {-Oー マロン酸 } & 0.0232 M \\
\text { - — " } & 0.0556 M
\end{array}
$$

Fig. 6 の $450 \mathrm{~m} \mu$ における二つの曲線からわかるよう に, マロン酸の濃度を相当増しても, 抽出試薬溶液の濃 度を少し増せば, バナジウムの抽出が妨げられない。

本法の許容 $\mathrm{pH}$ 範囲は十分広いので, 従来の $\mathrm{pH}$ 変 動許容範囲が $\pm 0.3^{4)}$ または $\pm 0.1^{6)}$ であるのに対し て有利である。すなわち，次のようにしてきわめて容易 に $\mathrm{pH}$ を調節できる. 試料溶液の遊離酸またはアルカリ を，2,4-ジニトロフェノール，フェノールフタレイン またはジメチルイエローを指示薬にして中和したの ち, 所定量の $\mathrm{pH}$ 緩衝溶液を加えると $\mathrm{pH}$ が約 3.4 K なる. この場合，マロン酸根が $0.05 M$ 程度になるので， $0.30 \mathrm{meq}$.の遊離の酸またはアルカリが中和されないで

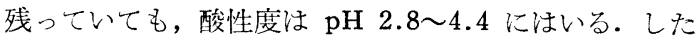
がって, pH 調節を誤る心配梳ない.なお, 中和に際し て生じる共存イオンの沈殿はマロン酸緩衝溶液を加元る と容易に溶ける.ブロムフェノールブルー, ブロムチモ ールブルー,コンゴーレッド，メチルオレンジなどは一 部または全部が抽出されて可視部の光を吸収するので， 中和指示薬として不適当である. 試料溶液にマロン酸范 加えてから $\mathrm{pH}$ を調節する場合には, 試料溶液が少し呈 色していても， pH 2.6〜4.0 で 2,4-ジニトロフェノー ルが無色から黄色に変わるのが認められるので,この指 示薬を用いるのが便利である.

\section{5 バナジゥムの量と吸光度との関係}

以上の検討結果から, マロン酸 $0.0556 M$ 以下, $\mathrm{pH}$ $2.8 \sim 4.4$, 容積 $25 \mathrm{ml}$ のバナジゥム溶液を, $0.144 \%$ 以 上の試薬を含む 3 -ヘプタノール $5 \mathrm{~m} l$ で 1 回抽出すれ ば, バナジウムが全部抽出されることがわかる.この条 件内で, マロン酸の濃度, $\mathrm{pH}$, 抽出試薬溶液の濃度な どを高值および低值が得られる傾向にいるいる組み合わ せ，0.0〜87.7 皇 のバナジウムを抽出して 検量線を求 


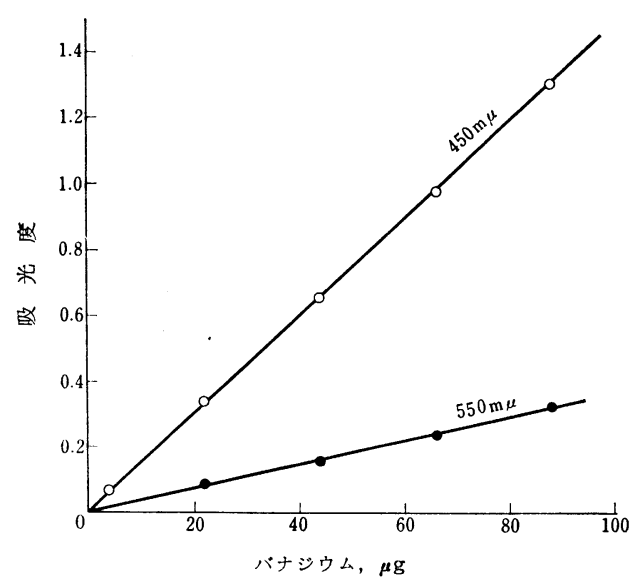

Fig. 7 検 量 線

マロン酸: 0.0227 および $0.0556 M$

$\mathrm{pH} \quad: 2.8 \sim 4.2$

抽出武薬溶液： 0.144 および $0.160 \%$ 溶液, $5.00 \mathrm{~m} l$

めた. その結果を Fig. 7 に示す. 吸光度はバナジウム の量に比例し, 吸収曲線の形は变わらない. $450 \mathrm{~m} \mu$ に おける検量線は

$$
\mathrm{V}(\mu \mathrm{g})=(67.484 \pm 0.352) A-(0.568 \pm 0.136)
$$

で表わされる ( $A$ は吸光度). 傾斜と切片のそれぞれの 標準偏差の和を定量值の標準偏差とすると,
標準偏差. $(\%)=0.52+\frac{13.6}{\mathrm{~V}(\mu \mathrm{g})}$

となり，直線性がきわめてよかった，定量下限は吸光度 0.05 までとるとバナジウム $2.81 \mu \mathrm{g}$ であり, 定量上限 は約 $90 \mu \mathrm{g}$ である.ほかの波長を用いると $90 \mu \mathrm{g}$ 以上 のバナジウムも定量できると思われる・ただし，モリブ デン（VI）による吸収妨害を避けるためには， $450 \mathrm{~m} \mu$ 以上における吸光度を測らなければならない。

\section{$3 \cdot 6$ 妨害イオン}

従来の抽出吸光定量法では, 数多くの金属元素が定量 を妨げる3 (6). 本法では $\mathrm{pH}$ 緩衝俞に用いられるマロン 酸が被覆剂になるので，金属元素による妨害が著しくお さえられる. Table IV に各種共存物による妨害の状態 と共存許容量を示す.

鉄 (III) は赤色錯化合物となって，従来の方法ではか なり抽出され，Fig. 8-曲線Iのような吸収を示して定 量を著しく妨げるが, 本法では $2.0 \mathrm{mg}$ までの共存は許 容される．もし，さらに他の被覆剂を加えるならば，鉄 の共存許容量をさらに増すことが可能である。たとえ ば，ピロリン酸ナトリウムを $0.02 M$ 加えると, 少なく とも $5 \mathrm{mg}$ まで鉄があってもさしつかえない. チタン （IV）錯化合物は抽出されて淡黄色を呈し，従来の方法 では著しい妨げになるが，本法に抢いては，鉄と同程度

Table IV 共存物の影響と共存許容量

\begin{tabular}{|c|c|c|c|c|c|c|}
\hline & & 共 & 加えた化合物 & 加えた量 (mg) & 定量誤差 (\%) & 許容量 $(\mathrm{mg}) \dagger$ \\
\hline & $\boldsymbol{P}$ & ル $\Sigma$ ウ ム & 硝酸アルミ゙ウム & 2.0 & -1.1 & 2.0 \\
\hline & 七 & 素 (IV) & ヒ酸水素二ナトリウム & 2.0 & -0.9 & 2.0 \\
\hline & ホ & 素 & 四ホウ酸ナトリウム & 2.5 & -2.3 & 2.5 \\
\hline & ク & 口 $\quad$ A (III) & 像酸 ク 口八 & 2.0 & -2.5 & 2.0 \\
\hline & ᄀ & ッ 素 & フッ化ナトリウム & 2.5 & -1.1 & 2.5 \\
\hline \multirow[t]{15}{*}{$\cdot$} & & 鉄 (III) & 塩 化 第 二 鉄 & $\begin{array}{l}1.0 \\
2.5\end{array}$ & $\begin{array}{l}-1.7 \\
+7.1\end{array}$ & 1.0 \\
\hline & & ン ガ ン (II) & 硫 酸 マ ン ガ ン & 2.5 & -2.6 & 2.5 \\
\hline & & リブ デン (VI) & モリブデン酸アンモニウム & $\begin{array}{l}0.50 \\
1.25\end{array}$ & $\begin{array}{l}-1.6 \\
-25.3\end{array}$ & 0.50 \\
\hline & リ & ン（正リン酸） & リン酸水素二ナトリウム & 10.0 & -2.3 & 10.0 \\
\hline & リ & ン（ピロリン酸） & ピロリン酸ナトリウム & 15.0 & -0.7 & 15.0 \\
\hline & 白 & 金 (IV) & 塩化 白 金 酸 & 1.25 & -2.0 & 1.25 \\
\hline & ト & リウ ム (IV) & 硝酸卜リウ & 2.5 & -0.7 & 2.5 \\
\hline & チ & タ ン (IV) & 硫 酸 チ タ ン & 2.0 & -3.0 & 2.0 \\
\hline & ウ & ラ ン (VI) & 酢 酸 ウ ラ = ル & 2.5 & -0.2 & 2.5 \\
\hline & & ングステン (VI) & タングステン酸ナトリウム & $\begin{array}{l}0.01 \\
0.001\end{array}$ & $\begin{array}{l}-3.8 \\
-15.0+\dagger\end{array}$ & 0.001 \\
\hline & & バルト(II), 銅(II), ニッケル & 硝 酸 塩と硫酸 㙁 & 各 1.25 & -0.7 & 各 1.25 \\
\hline & & アンイオン & シアン化カリウム & 2600 & 約 -9 & \\
\hline & 酒 & 石酸 イオン & カリウム・ナトリウム塩 & 1180 & -9.6 & \\
\hline & ク & エン酸イオン & ナト リ ウ & 1510 & -28.0 & \\
\hline & $\mathbf{E}$ & $\begin{array}{lll}\mathrm{D} & \mathrm{T} & \mathrm{A}\end{array}$ & 遊離 & 5850 & 約 -9 & \\
\hline
\end{tabular}

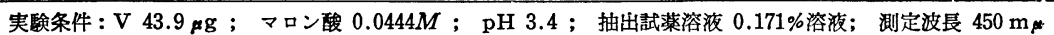
$\dagger \pm 3.0 \%$ 以下の誤差の許容量. † バナジウムを $3.0 \mu \mathrm{g}$ 用いて試験した. 


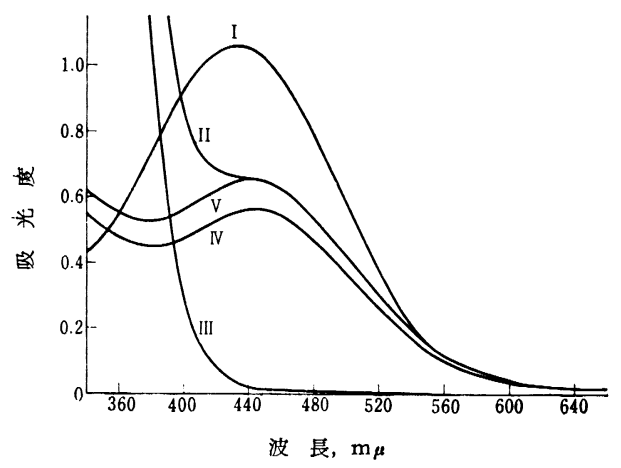

Fig. 8 鉄，モリブデン，タングステンなどによる 妨害の状態

マロン酸 : $0.0444 M ; \mathrm{pH}: 3.4 ; 0.171 \%$ 抽出試薬溶液

曲線 I : $\mathrm{Fe}$ (III), $200 \mu \mathrm{g}$ (ただしマロン酸なし)

" II : V $43.9 \mu \mathrm{g}+$ Mo (VI) $500 \mu \mathrm{g}$

"III : Mo (VI), $500 \mu \mathrm{g}$

" IV : V $43.9 \mu \mathrm{g}+\mathrm{W}$ (VI) $125 \mu \mathrm{g}$

" $\mathrm{V}: \mathrm{V} 43.9 \mu \mathrm{g}$

淿タンが其存してもさしつかえない。モリブデン(VI) とタングステン (VI) は本法でも従来法の場合と同じよ うに負の䛊差の原因となる.モリブデンは錯化合物と なって一部抽出され，Fig. 8-曲線 III で示すように短 波長の光を吸収する.このため，モリブデンがあるとき は $450 \mathrm{~m} \mu$ より短波長の光を定量に用いえない。なお， 抽出試薬溶液の濃度を増してもモリブデンとタングステ ンによる抽出妨害をおさえることができない。これは両 者による試薬の消費に基うくくのではなく，両者がバナジ ウムとへテロ絔合酸をつくるためであると思われる，モ リブデンとタングステンをフッ素, シアン, リン酸, ピ ロリン酸, ホウ酸, 酒石酸, クエン酸などのイオンで被 覆することを試みたが，どれも成功しなかった。な㧍， 3-ヘプタノールの水への溶解度が小さいので, 抽出層を マロン酸緩衝溶液で洗って, 妨害イオンの共存許容量を 増すことができよう。

本研究を励ましてくださった東北大学教授小野健二, 岡好良両先生に感謝するとともに, 発表を許可された 東海電極製造株式会社に礼を述べる.

(昭和 38 年 4 月, 日本化学 会第 16 年会に扣いて講演)

\section{交献}

1) M. M. Singh, A. K. Das Gupta : J. Sci. Ind. Research (India), 8B, 186 (1949); Chem. Abstr., 44, 2885 (1950).

2) A. K. Das Gupta, M. M. Singh : J. Sci. Ind. Research (India), 11B, 268 (1952); Chem. Abstr., 47, 10405 (1953).
3) W. M. Wise, W. W. Brandt : Anal. Chem., 27, 1392 (1955).

4) P. R. Kuehn, O. H. Howard, C. W. Weber : ibid., 33, 740 (1961).

5) F. H. Hulcher : ibid., 32, 1183 (1960).

6) G. B. Jones, J. H. Watkinson : ibid., 31, 1344 (1959).

7）日本化学会編：“実験化学講座”, 第 9 巻, p. 273 (1958), (丸善).

8) 宮本正俊：本誌，12，32 (1963).

9) H. Compaan : Nature, 180, 980 (1957).

10) C. D. Hodgman : "Handbook of Chemistry and Physics", 38th Ed., (1956), (Chemical Rubber Publishing, Cleaveland, Ohio).

11) C. E. Meloan, W. W. Brandt : Anal. Chem., 33, 102 (1961).

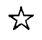

An improved extraction-absorptiometry for the determination of microamounts of vanadium as a brown complex with benzohydroxamic acid. (Absorptiometric determination of microamounts of vanadium. I.) Masatoshi Мгчамото* and Masatake KATAGIRI** (*Tohoku College of Pharmacy, Sendai; **Nippon Poriuretan Kogyo K. K., Hodogaya-ku, Yokohama)

In the extraction-spectrophotometric determination of microamounts of vanadium (V) by benzohydroxamic acid, a pH-buffer solution simultaneously acting as a masking agent for interfering metals was used, and the color reaction and the extraction were done in one step by shaking with an organic solvent containing the reagent in order to avoid the difficulties hitherto reported as to the stability of the complex in the aqueous phase, the stability of organic extractants, and the preparation of the aqueous reagent solution. The proposed reagent solution was stable at least for 2 months. A wider optimum $\mathrm{pH}$ range was given for the extraction.

Procedure $: \mathrm{pH}$ of a solution containing 2.8 to about $90 \mu \mathrm{g}$ vanadium $(\mathrm{V})$ is adjusted to $2.8 \sim 4.4$ by adding $4.0 \sim 5.0 \mathrm{ml}$ of a malonate buffer consisting of 5 parts of $0.5 \mathrm{M}$ malonic acid and 1 part of $0.5 M$ sodium malonate after the solution is roughly neutralized against phenolphthalein or 2,4-dinitrophenol. Dilute the solution to $25 \mathrm{ml}$ and shake it for $3 \mathrm{~min}$. with $5.00 \mathrm{ml}$ of $0.144 \sim$ $0.171 \%$ extracting reagent solution in 3-heptanol. Resulting organic layer is ready for the absorption measurement at $450 \mathrm{~m} \mu$ with $1 \mathrm{~cm}$ cells against water. The color is stable for at least 2 days. Permissible amounts of common diverse ions including titanium (IV) are individually $2.0 \mathrm{mg}$ at least. The amounts of $\mathrm{Fe}$ (III), Mo (VI), Pt (IV), or W (VI) should not exceed 1.0, $0.5,1.25$, or $0.001 \mathrm{mg}$, respectively. The addition of $0.02 M$ sodium pyrophosphate improved the permissible amounts of $\mathrm{Fe}$ to $5 \mathrm{mg}$.

(Received Nov. 28, 1964) 